Artikel Penelitian

\title{
Hubungan Daerah Tempat Tinggal dengan Gambaran Histopatologi Karsinoma Tiroid pada Masyarakat Sumatera Barat
}

\author{
Eka Putri ${ }^{1}$, Daan Khambri ${ }^{2}$, Selfi Renita Rusjdi ${ }^{3}$
}

\section{Abstrak}

Karsinoma tiroid dapat dibagi berdasarkan gambaran histopatologi menjadi tipe papiler, folikuler, meduler dan anaplastik. Salah satu faktor yang mempengaruhi gambaran histopatologi karsinoma tiroid adalah keadaan geografis, dimana karsinoma tipe folikuler dan anaplastik akan lebih sering ditemukan pada daerah beresiko defisiensi yodium dibandingkan daerah tidak beresiko defisiensi yodium. Tujuan penelitian ini adalah menentukan hubungan antara daerah tempat tinggal dan gambaran histopatologi karsinoma tiroid. Penelitian ini menggunakan desain analitik observasional dengan mengumpulkan data sekunder di Laboratorium Patologi Anatomi FK Unand dan rekam medik RSUP M. Djamil periode Januari 2010 sampai Desember 2011. Hasil penelitian ini ditemukan 102 kasus karsinoma tiroid, dimana 32 kasus bertempat tinggal di daerah beresiko defisiensi yodium dan 70 kasus bertempat tinggal di daerah tidak beresiko defisiensi yodium. Pada daerah beresiko defisiensi yodium, 34,4\% merupakan karsinoma folikuler dan anaplastik, dan $65,5 \%$ merupakan karsinoma selain folikuler dan anaplastik. Pada daerah tidak beresiko defisiensi yodium, 22,9\% merupakan karsinoma folikuler dan anaplastik, dan 77,1\% merupakan karsinoma selain folikuler dan anaplastik. Analisis statistik hubungan antara daerah beresiko defisiensi yodium dan kejadian karsinoma folikuler dan anaplastik berdasarkan uji chi-square didapatkan nilai $p=0,33$. Simpulan penelitian ini ialah tidak terdapat hubungan bermakna antara daerah tempat tinggal dengan gambaran histopatologi karsinoma tiroid pada masyarakat Sumatera Barat pada periode Januari 2010 sampai Desember 2011.

Kata kunci: karsinoma tiroid, histopatologi,daerah tempat tinggal

\section{Abstract}

Thyroid carcinomas on histopathological types are divided into papillary carcinoma, follicular carcinoma, medullary carcinoma and anaplastic carcinomas. Factors that can influence the histopathological type of thyroid carcinomas is geographical factor, which follicular and anaplastic type of thyroid carcinomas more frequently found in areas at risk of iodine deficiency than the area not at risk of iodine deficiency. The objective of this study was to determine the relationship between residential areas and histopathologic types of thyroid carcinoma. This analytic research with observational design obtaining secondary data from Pathology Anatomy Laboratory of Medical Faculty of Andalas University and medical record of M. Djamil Hospital in a period of January 2010 - December 2011. The result found 102 cases of thyroid carcinoma, of which 32 cases residing in areas at risk of iodine deficiency and 70 cases residing in the area were not at risk of iodine deficiency. In areas at risk of iodine deficiency, 34.4\% are follicular and anaplastic carcinomas and $65.5 \%$ are papillary carcinomas. In areas not at risk of iodine deficiency, $22.9 \%$ are follicular and anaplastic carcinomas, and $77.1 \%$ are papillary carcinomas. Statistical analysis of the relationship between the area at risk of iodine deficiency and follicular and anaplastic carcinoma incidence by chi-square test $p$ value $=0.33$. The conclusion is no significant correlation between residential areas and histopathological types of thyroid carcinoma of West Sumatera society.

Keywords: Thyroid carcinoma, histopathological, residential areas 
Affiliasi penulis: 1. Prodi Profesi FK Unand (Fakultas Kedokteran Universitas Andalas Padang), 2. Bagian Bedah FK Unand/RSUP Dr. M.Djamil Padang, 3. Bagian Parasitologi FK Unand

Korespondensi: Eka Putri, Email: ti_uty@yahoo.com, Telp: 0751 496115

\section{PENDAHULUAN}

Karsinoma tiroid merupakan keganasan kelenjar endokrin yang paling sering ditemukan yaitu sekitar 95\% dari seluruh keganasan endokrin. Insiden karsinoma tiroid meningkat sekitar $7 \%$ setiap tahunnya, peningkatan insiden lebih cepat dibandingkan kanker solid jenis lain. Angka kejadian karsinoma tiroid bervariasi di seluruh dunia, yaitu sekitar 0,5-10 jiwa per 100.000 populasi. ${ }^{1}$

Karsinoma tiroid berdasarkan gambaran histopatologinya dibagi menjadi karsinoma tipe papiler, folikuler, meduler, dan anaplastik. Angka kejadiannya bervariasi, yakni: tipe papiler $60-80 \%$, tipe folikuler $10-27,5 \%$, tipe medular $3-10 \%$, dan tipe anaplastik $3-8 \%$. Dari segi agresifitas, karsinoma tipe anaplastik memiliki prognosis paling buruk, dimana angka kematiannya hampir $100 \%$, disusul oleh tipe meduler dengan angka harapan hidup dalam 10 tahun sebesar $65 \%$. Tipe folikuler dan papiler prognosisnya lebih baik, angka kematian dalam 30 tahun pertama pada tipe folikuler sebesar $15 \%$ dan papiler $6 \%{ }^{2}$

Salah satu faktor yang mempengaruhi gambaran histopatologi karsinoma tiroid adalah asupan yodium. Asupan yodium ditentukan oleh kandungan yodium yang terdapat di alam. Kandungan yodium suatu daerah dipengaruhi oleh keadaan geografisnya, dimana sering ditemukan daerah kekurangan yodium atau yang sering dikenal dengan sebutan daerah endemik goiter di dataran tinggi dan pegunungan. ${ }^{3}$ Hal tersebut disebabkan karena curah hujan yang tinggi di daerah pegunungan dan keadaan topografi yang relatif curam dan bergelombang sehingga lebih sering terjadi erosi dan menyababkan yodium larut dan terkikis dari tanah. ${ }^{4}$
Rendahnya kadar yodium pada daerah tersebut berasosiasi pada peningkatan frekuensi karsinoma tiroid tipe folikuler dan anaplastik dan menurunkan frekuensi tipe papiler. Pada penelitian yang dilakukan pada hewan percobaan, pemberian suplemen yodium mengubah morfologi karsinoma tiroid dari tipe folikuler menjadi papiler. Hal ini mengindikasikan bahwa peran dari yodium dalam karsinogenesis tiroid adalah lebih kepada memodulasi morfologi tumor dari pada menginisiasi kanker. ${ }^{5}$

\section{METODE}

Penelitian ini merupakan studi analitik observasi dengan pendekatan cross-sectional yang bertujuan untuk mengetahui hubungan daerah tempat tinggal dengan gambaran histopatologi karsinoma tiroid. Sampel penelitian yaitu semua semua pasien karsinoma tiroid yang diperiksa dan didiagnosis karsinoma tiroid di Labor Patologi Anatomi FK Unand. Kriteria inklusi sampel penelitian adalah pasien yang bertampat tinggal di daerah Sumatera Baratdan kriteria eksklusi adalah pasien yang tinggal di daerah selain Sumatera Barat. Variabel dependen dari penelitian ini adalah gambaran histopatologi karsinoma tiroid, sedangkan variabel independen adalah daerah tempat tinggal. Penelitian ini dilakukan di Laboratorium PatologiAnatomi FK Unand dan Rekam Medik RSUP Dr. M. Djamil Padang selama tiga bulan, yakni dari bulan Oktober sampai Desember 2013. Langkah-langkah pengolahan data adalah pemeriksaan kelengkapan dan kejelasan data, pemberian kode pada setiap data variabel, memasukkan data ke dalam komputer, serta pemeriksaan kembali untuk memastikan bahwa data tersebut telah bersih dari kesalahan. Analisis data terdiri dari analisis univariat dan bivariat. Pada analisis bivariat dicari hubungan antara dua variabel dengan menggunakan uji chi-square. 
HASIL

\section{Karakteristik Karsinoma Tiroid}

Tabel 1. Karakteristik Karsinoma tiroid yang terdapat pada masyarakat Sumatera Barat

\begin{tabular}{lll}
\hline & Jumlah & Persentase \\
\hline Tahun Kejadian & & \\
2010 & 26 & $25,5 \%$ \\
2011 & 76 & $74,5 \%$ \\
Jenis Kelamin & & \\
$\quad$ Perempuan & 83 & $81,4 \%$ \\
$\quad$ Laki-laki & 19 & $18,6 \%$ \\
Umur & & \\
$<=20$ & 11 & $10,8 \%$ \\
$21-30$ & 27 & $26,5 \%$ \\
$31-40$ & 21 & $20,6 \%$ \\
$41-50$ & 18 & $17,6 \%$ \\
$51-60$ & 15 & $14,7 \%$ \\
61-70 & 5 & $4,9 \%$ \\
$>=71$ & 5 & $4,9 \%$ \\
Gambaran Histopatologi & & \\
$\quad$ Karsinoma papiler & & \\
Karsinoma folikuler & 75 & $73,5 \%$ \\
$\quad$ Karsinoma anaplastik & 22 & $21,6 \%$ \\
$\quad$ Karsinoma meduler & 5 & $4,9 \%$ \\
\hline
\end{tabular}

Insiden karsinoma tiroid dari tahun 2010 sampai 2011 terdapat 102 kasus. Kejadian karsinoma tiroid lebih sering terjadi pada wanita dengan persentase sebesar $81,4 \%$.Pada penelitian ini diketahui bahwa insiden karsinoma tiroid dapat terjadi di semua kelompok umur. Insiden tertinggi karsinoma tiroid terdapat pada kelompok umur 21-30 tahun sebanyak 27 kasus (26,5\%). Berdasarkan gambaran histopatologi, karsinoma tiroid yang paling sering ditemukan adalah tipe papiler dengan kejadian 75 kasus $(73,5 \%)$, sedangkan tipe meduler tidak ditemukan pada masyarakat Sumatera Barat selama periode 2010 sampai 2011.

Ada 32 kasus karsinoma tiroid yang ditemukan pada daerah beresiko defisiensi yodium, terdapat 21 kasus karsinoma tipe papiler $(65,6 \%), 7$ kasus karsinoma tipe folikuler $(21,9 \%)$ dan 4 kasus karsinoma tipe anaplastik (12,5\%). Dari 70 kasus yang ditemukan pada daerah tidak beresiko defisiensi yodium, didapatkan 54 kasus karsinoma tipe papiler $(77,1 \%), 15$ kasus karsinoma tipe folikuler $(21,4 \%)$ dan 1 kasus karsinoma tipe anaplastik $(1,4 \%)$.

\section{Hubungan Daerah Tempat Tinggal dengan Gambaran Histopatologi Karsinoma Tiroid}

Tabel 2. Hubungan daerah tempat tinggal dengan gambaran histopatologi karsinoma tiroid

\begin{tabular}{|c|c|c|c|c|c|}
\hline \multirow{2}{*}{\multicolumn{2}{|c|}{$\begin{array}{l}\text { Kategori } \\
\text { Defisiensi } \\
\text { Yodium }\end{array}$}} & \multicolumn{2}{|c|}{$\begin{array}{l}\text { Karsinoma Folikuler } \\
\text { dan Anaplastik }\end{array}$} & \multirow[t]{2}{*}{ Total } & \multirow[t]{2}{*}{$p$} \\
\hline & & ya & tidak & & \\
\hline \multirow[t]{2}{*}{ Beresiko } & $f$ & 11 & 21 & 32 & \\
\hline & $\%$ & $34,4 \%$ & $65,6 \%$ & $100 \%$ & \\
\hline Tidak & $f$ & 16 & 54 & 70 & 0,33 \\
\hline beresiko & $\%$ & $22,9 \%$ & $77,1 \%$ & $100 \%$ & \\
\hline \multirow[t]{2}{*}{ Total } & $f$ & 27 & 75 & 102 & \\
\hline & $\%$ & $26,5 \%$ & $73,5 \%$ & $100 \%$ & \\
\hline
\end{tabular}

Pengolahan data menggunakan metode chisquare pada Tabel 2 di atas, didapatkan nilai $p=0,33$ (dimana nilai $p$ dianggap bermakna bila $p<0,05$ ) yang berarti bahwa tidak ada hubungan yang bermakna antara daerah beresiko defisiensi yodium dengan peningkatan kejadian karsinoma tiroid tipe folikuler dan anaplastik.

\section{PEMBAHASAN}

\section{Karakteristik Karsinoma Tiroid}

Pada penelitian ini terlihat bahwa insiden karsinoma tiroid pada tahun 2011 mengalami peningkatan tiga kali lipat dibandingkan tahun sebelumnya. Karsinoma tiroid lebih banyak dialami oleh perempuan dibandingkan laki-laki dengan perbandingan 4,5:1. Hal ini sesuai dengan teori dan data epidemiologi sebelumnya yang menyatakan bahwa karsinoma tiroid 2-4 kali lebih sering terjadi pada perempuan. Faktor penyebab lebih tingginya insiden pada perempuan adalah terkait hormon reproduksi. Pada kelenjar tiroid normal, tumor jinak, dan tumor ganas tiroid terdapat reseptor estrogen dan progesteron dalam jumlah bervariasi. ${ }^{6}$

Gambaran karsinoma tiroid yang paling sering terjadi adalah tipe papiler $(73,5 \%)$, disusul tipe folikuler $(21,6 \%)$, dan tipe anaplastik (4,9\%), sedangkan tipe meduler tidak ditemukan pada penelitian ini. Hasil penelitian ini sejalan dengan kepustakaan yang menyatakan bahwa insiden kasus 
karsinoma tiroid yang paling sering terjadi adalah tipe papiler dan yang paling jarang terjadi tipe meduler dan anaplastik. $^{7}$

\section{Hubungan Daerah Tempat Tinggal dengan Gambaran Histopatologi Karsinoma Tiroid}

Secara analisis statistik berdasarkan uji chisquare, didapatkan nilai $p=0,33 \quad(p>0,05)$ yang berarti tidak terdapat perbedaan bermakna antara daerah defisiensi yodium dengan peningkatan kejadian karsinoma tiroid tipe folikuler dan anaplastik.

Penelitian ini tidak sejalan dengan data epidemiologi sebelumnya yang menyatakan bahwa akan ditemukan peningkatan frekuensi karsinoma folikuler dan anaplastik pada daerah defisiensi yodium dibandingkan daerah tinggi yodium. ${ }^{8}$

Ketidaksesuaian hasil penelitian dengan studi sebelumnya dapat disebabkan oleh adanya faktor lain yang juga mempengaruhi rendahnya asupan yodium atau terjadinya Gangguan Akibat Kurang Yodium (GAKY) selain faktor geografi, yakni faktor lingkungan. Lingkungan yang banyak terdapat zat goitrogenik terutama kelompok thiosianat yang terapat pada ubi kayu, jagung, rebung, ubi jalar dan buncis dapat meningkatkan kejadian GAKY. Konsumsi zat goitrogenik, akan menghambat penyerapan yodium dalam tubuh. ${ }^{3}$ Ketidaksesuaian hasil penelitian ini dengan kepustakaan juga dapat disebabkan karena adanya faktor lain yang dapat mempengaruhi gambaran histopatologi karsinoma tiroid selain asupan yodium, yakni adanya paparan radiasi terutama radiasi eksternal yang akan menyebabkan peningkatan frekuensi karsinoma tiroid tipe papiler, dan adanya faktor genetik yang terkait karsinoma tipe meduler. ${ }^{8}$

\section{SIMPULAN}

Tidak terdapat hubungan yang bermakna antara daerah tempat tinggal dengan gambaran histopatologi karsinoma tiroid yang diperiksa di Laboratorium Patologi dan Anatomi Fakultas Kedokteran Universitas Andalas dan RSUP M. Djamil pada periode Januari 2010 sampai Desember 2010.

\section{DAFTAR PUSTAKA}

1. Harris PE. Carcinoma of thyroid. Dalam: DeVita VT, Hellman S, Rosenberg SA, editor (penyunting). Cancer, principles \& practice of oncology. Edisi ke-7. Philadelphia: Lippincott Williams \& Wilkins; 2005.hlm.107-14

2. Desen W. Buku ajar ongkologi klinis. Edisi ke-2. Jakarta: Fakultas Kedokteran Universitas Andalas; 2011.

3. Djokomoeljanto R. Buku ajar tiroidologi klinik. Semarang: Universitas Diponegoro; 2007

4. Saidin S. Hubungan keadaan geografi dan lingkungan dengan Gagguan Akibat Kurang Yodium (GAKY). Media Litbang Kesehatan. 2009; 19(2).

5. Kasagi K. Epidemiology of thyroid tumors: effect of environmental iodine intake. Japanese Journal Of Clinical Medicine (NihonRinsho). 2007;65(11): 1953-61.

6. Kumar A,. Estradiol-induced proliferation of papillary and follicular thyroid cancer cells is mediated by estrogen receptors A and B. International Journal Of Oncology.2010;36:1067-80.

7. Lairmore TC, Moley JF. Cancer of endocrine system. Dalam: Harris PE, Bouloux PMG, editor. Endocrinology in clinical practice. United Kingdom: Martin Dunitz; 2003.hlm.1489-520

8. Steven I, Sherman SI. Thyroid carcinoma. Lancet. 2003;361: 501-11 